\title{
Plantar Carcinoma Cuniculatum, A Report After Five Years of Follow Up
}

\author{
Gabriele De Sena*1,2, Antonio Giordano ${ }^{2,4}$, Giovanni Giordano ${ }^{2}$, Alfredo Allariaa, ${ }^{1,2}$, Danilo \\ Porpora $^{1,2}$, Rosa D’Amico ${ }^{1,2}$, Marica Grasso ${ }^{4}$ and Vincenzo Napolitano ${ }^{1,3}$ \\ ${ }^{1}$ Department of Translational Medical Sciences, University of Campania Luigi Vanvitelli, Italy \\ ${ }^{2}$ Integrated Assistential Department of General and Special Surgery, University of Campania Luigi Vanvitelli, Italy \\ ${ }^{3}$ UOSD Endoscopic Surgery, University of Campania Luigi Vanvitelli, Italy \\ ${ }^{4}$ UOS Vascular Surgery, University of Campania Luigi Vanvitelli, Italy
}

${ }^{5}$ Faculty of Medicine, Surgery and Dentistry, University of Salerno. Salerno, Italy

*Corresponding author: Gabriele De Sena, Department of Translational Medical Sciences, University of Campania Luigi Vanvitelli (Italy) - Integrated Assistential Department of General and Special Surgery (Cappella Cangiani). UOSD Endoscopic Surgery, Via

Pansini 5-80138, Naples, Italy

\section{ARTICLE INFO}

Received: 幽 February 05, 2020

Published: 慧 February 28, 2020

Citation: De Sena G. Giordano A. Giordano G. Allaria A. Porpora D. et al., Plantar Carcinoma Cuniculatum, A Report After Five Years of Follow Up. Biomed J Sci \& Tech Res 26(1)2020. BJSTR. MS.ID.004308.

\section{ABSTRACT}

The C. Cuniculatum CC of the foot is rare and unknown; CC has a high index of local invasiveness. The surgery give great results and the prognosis is good but it depends on the time of the diagnosis. Exist a risk of a recurrence so it needs follow up.

Keywords: Carcinoma Cuniculatum; Squamous Cell Carcinoma; Verrucous Carcinoma

Abbreviations: VC: Verrucous Carcinoma, SCC: Squamous Cell Carcinoma, CC: Carcinoma Cuniculatum

\section{Introduction}

Verrucous Carcinoma (VC), described by L.V. Ackerman in 1948 , is extremely rare [1]; it has a high index of local invasiveness. It represents a variant of Squamous Cell Carcinoma (SCC) about $1-10 \%$ of cases of SCC [2]. There is a wide nomenclature it depends on the location of the lesion and on its clinical presentation [3], for this reason we have: plantar Carcinoma Cuniculatum (CC), giant condyloma acuminata of the genital region, verrucous carcinoma of the oropharynx, papillomatous carcinoma of the skin, epithelioid tumor, squamous carcinoma of the skin, etc. [4]. We report a rare case of plantar CC that occurred in our Surgical Department after five years of follow up.

\section{Case History}

A 63 years old man, smoker, suffering from type II diabetes mellitus in treatment with oral hypoglycemic drugs, essential arterial hypertension, chronic venous hypertension in the lower limbs for which he underwent internal saphenectomy surgery two years before, come whit trophic lesion of the right foot a supposed result of a previous surgical excision performed in another Hospital two years earlier result of a previous surgical excision performed in another Hospital (no histological examination was performed). On physical examination we appreciated at the plantar level of the right foot between the first and second metatarsus a trophic lesion, which was present from two years, it has poorly defined edges with a healthy and torpid base, the perilesional skin appeared as a vast area of reddish appearance, partly with an orange peel appearance, in this area we have identified numerous fistulous tracts (Figure 1) from which frankly purulent and smelly material was secreted (Figure 2). These fistulous tramites also reached the back of the foot and the interdigital folds; the cribiform area extended to the arch of the foot and the most prominent part from the fifth metatarsal to the sole of the foot. 


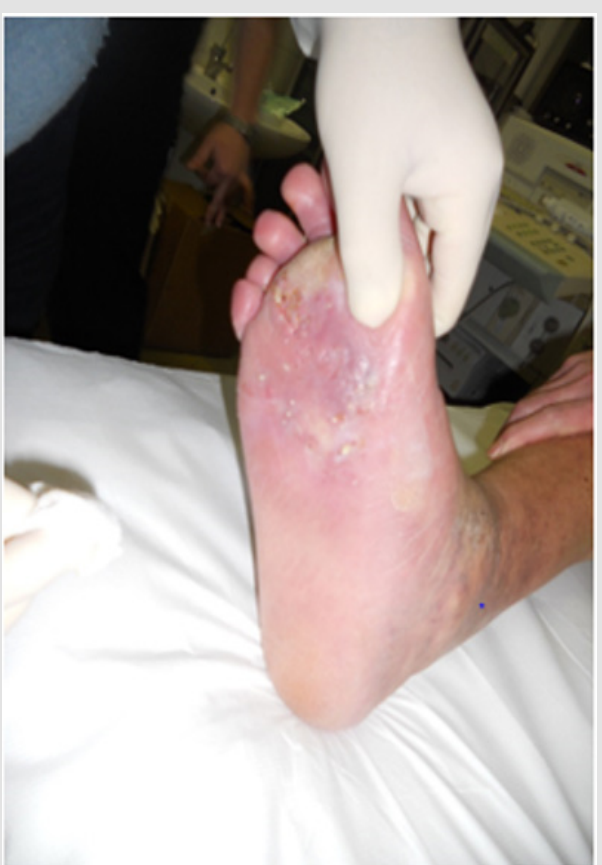

Figure 1: Right foot: vast area of reddish appearance in with it easy to identifie numerous fistulous tracts.

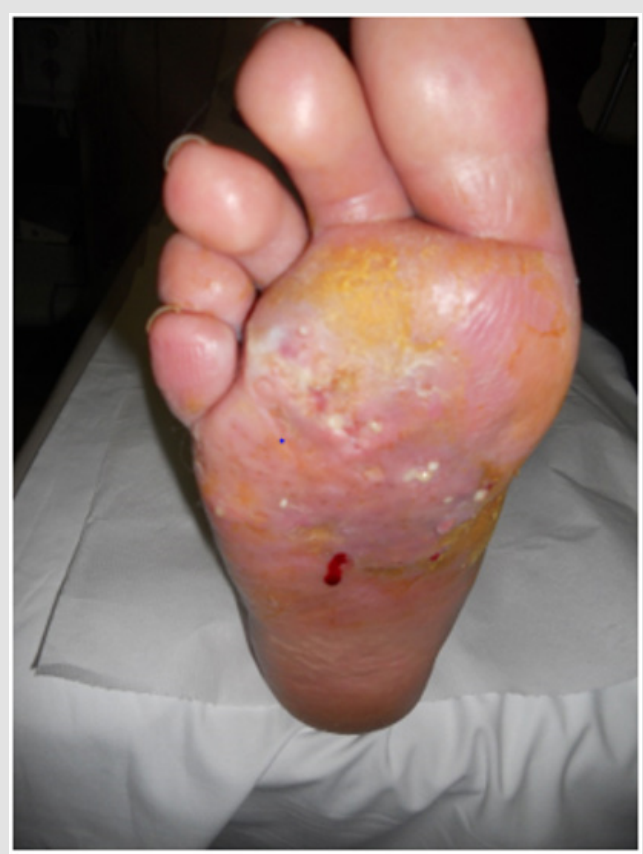

Figure 2: Right foot: fistulous tracts from which frankly purulent and smelly material was secreted.

\section{Diagnostic Procedures}

a) Blood tests showed a non-specific modification (Table 1)

b) Culture of purulent material was negative both for bacteria and for fungus.

c) X-ray of right foot showed morphostructural alterations of the third, fourth and fifth radii with loss of bone substance more evident at the fourth radius and marked demineralization [5]. d) Histological examination of a sample of skin obtained through an incisional biopsy showed a squamous carcinoma with aspects of the cuniculatum form.

e) Oncological visit.

f) Dermatological visit.

g) Full-body CT with contrast: at the chest "millimetric micronodulations in correspondence of the small fissure and of the left fissure from verosimiliti phlogistic outcomes. Gallbladder with inhomogeneous content due to the presence of some calculations. Atheromasia of the abdominal aorta. Enlarged lymph node in the right obturator site, spherical symmetry lymph nodes, with loss of typical morphology in the left and right groin region".

Table 1: Baseline clinical and laboratory characterization of the patient.

\begin{tabular}{|c|c|}
\hline Clinical Characteristics & Baseline (day 1) \\
\hline Age (Years) & 63 \\
\hline Height $(\mathrm{cm})$ & 185 \\
\hline Body Weight (Kg) & 80 \\
\hline BMI $\left(\mathrm{Kg} / \mathrm{m}^{2}\right)$ & 23,4 \\
\hline Fever $\left({ }^{\circ} \mathrm{C}\right)$ & 35,9 \\
\hline White blood cells $\left(\mathrm{x} 10^{3} / \mu \mathrm{L}\right)$ & 9,8 \\
\hline Neutrophil $\left(\mathrm{x} 10^{3} / \mu \mathrm{L}\right)$ & 6,97 \\
\hline Neutrophil (\%) & 71,1 \\
\hline Lymphocytes $\left(\mathrm{x} 10^{3} / \mu \mathrm{L}\right)$ & 2,12 \\
\hline Lymphocytes (\%) & 21,6 \\
\hline Monocytes $\left(\mathrm{x} 10^{3} / \mu \mathrm{L}\right)$ & 0,63 \\
\hline Monocytes (\%) & 6,4 \\
\hline Hemoglobin $(\mathrm{g} / \mathrm{dL})$ & 13,3 \\
\hline Hematocrit (\%) & 38,5 \\
\hline Platelets $\left(\mathrm{x} 10^{3} / \mu \mathrm{L}\right)$ & 274 \\
\hline $\operatorname{Albumin}(\mathrm{g} / \mathrm{dL})$ & 4 \\
\hline Total Protein $(\mathrm{g} / \mathrm{dL})$ & 8,4 \\
\hline Iron $(\mathrm{mcg} / \mathrm{dL})$ & 39 \\
\hline Sodium (mmol/L) & 140 \\
\hline Potassium (mmol/L) & 5,6 \\
\hline Ferritin $(\mathrm{ng} / \mathrm{mL})$ & 346 \\
\hline Calcium (mg/dL) & 9,8 \\
\hline C Reactive Protein (mg/dL) & 5,91 \\
\hline Fibrinogen (mg/dL) & 656,46 \\
\hline Partial Thromboplastin Time [APTT] (sec) & 27,3 \\
\hline Prothrombin time [PT] Activity (\%) & 100,2 \\
\hline Antithrombin III [\%] & 91,7 \\
\hline PT/International Normalized ratio [INR] & 1,01 \\
\hline Amylase U/L & 39 \\
\hline HBsAg & Neg. \\
\hline HCVAB & Neg. \\
\hline Glycemia (mg/dL) & 148 \\
\hline
\end{tabular}




\section{Treatment and Histological Findings}

Treatment was surgery consisting of amputation of forefoot at the level of the Chopard mediotarsic articulation and bilateral inguinal lymphadenectomy, healing occurred due to second intension. The result of the histological examination was squamous carcinoma, cuniculatum and infiltrating form. The soft tissues of the proximal margin was free from injury, the bone margin subjected to decalcification was free of injury. Lymph nodes appear to be affected by reactive hyperplasia and partial adipose metaplasia.

\section{Outcome and Follow-up}

On the seventh day of admission the improvement in her clinical condition was evident. Therefore, based on this, he was discharged home in stable condition on the 7 th day. At discharge, an oral antibiotic (Amoxicillin + Clavulanic acid $850+150 \mathrm{mg}$, every 12 hours) and surgical dressings every two days was prescribed for seven days. Periodic clinical checks were made for 4 months until the complete healing of the surgical wound occurred by second intention. He practiced a total body CT scan at 12 months and at 24 months and clinical monitoring every year for 5 years. After 5 years of follow up there was no clinical recurrence of the disease.

\section{Discussion}

Carcinoma Cuniculatum (CC) is a subtype of a low-grade squamous cell carcinoma SCC [6-10].The pathogenesis of these lesions is not fully understood [7], there seems to be an association with CC has a higher incidence in males between the 4th and 6th decades of life [11]. It has a chronic clinical course, evolving from a small focal lesion to a broad, fungiform and deep penetrating mass. Its slow growth during the initial phase is responsible for delays in diagnosis from eight to 15 years a7. Clinically, there is an exophytic or endophytic neoformation, ulcerated or not, with numerous fistulous passages from which debris of purulent and malodorous keratin originate in various anatomical sites [12]. The clinic should guide the diagnosis, but it is based on the histo-pathological results [13]. Clinically among the possible differential diagnoses, there are viral warts, pseudo-carcinomatous hyperplasia and deep mycoses [14]. Histologically it looks similar to plantar warts [15], there are well differentiated pale keratinocytes and there is a marked ipercheratosis and papillomatosis, there may be the formation of corneal pearls. Neoplastic branches can extend deep into the dermis and subcutaneously, forming intraepidermal abscesses filled with keratin and sinusoids connected to the epidermal surface called rabbit burrow [16]. The recommended treatment is the wide local excision, although the margins are often not clearly delimited during the intraoperative phase so that the exision must be wider, there is no agreement about lymphadenectomy [17]. The other therapeutic options are topical chemotherapy, cryotherapy and laser therapy, but they are indicated when the diagnosis is early and but they are burdened by a high rate of recurrences. Radiotherapy does not seem effective. Risk of recurrence is due to its local invasiveness [18], to inappropriate non surgical therapy and to a non radical surgical therapy [19].

\section{Conclusion}

Plantar carcinoma cuniculatum is extremely rare, the diagnosis often occurs late when, due to the clinical presentation, the only effective therapy is a vast surgical curettage or a partial or radical amputation of the foot. Long-term prognosis is excellent if there are no excessive diagnostic delay, healing rates reach $99 \%$. Patients should be reviewed annually for the risk of recurrence.

\section{References}

1. Ackerman LV (1948) Verrucous carcinoma of the oral cavity. Surgery 23: 670.

2. Schwartz RA (1995) Verrucous carcinoma of the skin and mucosa. J Am Acad Dermatol 32(1): 1-21.

3. David John Tobias McArdle, John Patrick McArdle, Frances Lee, Emilio Dino Mignanelli (2017) Rare "Inverted" Verrucous Carcinoma (Carcinoma Cuniculatum) of the Sacrogluteal Region: Case Report and Literature Review, International Journal of Surgical Pathology 25(5): 438-442.

4. Koch BB, Trask DK, Hoffman HT, Karnell LH, Robinson RA, et al. (2001) National survey of head and neck verrucous carcinoma: patterns of presentation, care, and outcome. Cancer 92: 110-120.

5. Yip KM, Lin Yip J, Kumta S, Leung PC (1997) Subcutaneous verrucous carcinoma with bone invasion. Am J Dermatopathol 19: 83-86.

6. Brownstein MH, Shapiro L (1976) Verrucous carcinoma of skin: Epithelioma cuniculatum plantare. Cancer 38(4): 1710-1716.

7. Kunze E, Burchhardt H, Schweyer S, Thielke-Neitzel K (2006) Epithelioma cuniculatum plantare in the region of a skin scar due to mechanical trauma. Insurance law aspects of scar carcinomas. Abteilung Osteopathologie und Hämatopathologie 109(9): 809-814.

8. Garven TC, Thelmo WL, Victor J, Pertschuk L (1991) Verrucous carcinoma of the leg positive for human papillomavirus DNA 11 and 18: A case report. Hum Pathol 22(11): 1170-11773.

9. Lee MY, Shin JC, Park CI, Rha DW, Sastry TK (2004) Verrucous carcinoma of the foot from chronic pressure ulcer. Spinal Cord 42: 431-434.

10. Verma S (2005) A verrucous carcinoma of the foot on an injection site: A case report. Int J Low Extrem Wounds 4: 252.

11. Green JG, Ferrara JA, Haber JA (1998) Epithelioma cuniculatum plantare. J Foot Surg 26(1): 78-83.

12. Dogan G, Oram Y, Hazneci E, Ozen S, Karincaoglu Y, et al. (1998) Three cases of verrucous carcinoma. Australas J Dermatol 39: 251-254.

13. Vanessa Di Palma, Jill P Stone, Andrew Schell, Jeffrey C Dawes (2018) Diabetic Ulcers: A Case of Bilateral Foot Verrucous Carcinoma, Case Reports in Dermatological Medicine p. 1-3.

14. Mc Cann JJ, Al-Nafussi AI (1998) Epithelioma cuniculatum plantare. Br J Plast Surg 42: 79-82.

15. Wright PK, Vidyadharan R, Jose RM, Rao GS (2004) Plantar verrucous carcinoma continues to be mistaken for verruca vulgaris. Plast Reconstr Surg 113(3): 1101-1103.

16. Spyriounis P, Tentis D, Sparveri I, Arvanitis T (2004) Plantar epithelioma cuniculatum. A case report with review of the literature. Eur J Plast Surg 27: 253-256.

17. Yoshitatsu S, Takagi T, Ohata C, Kozuka T (2001) Plantar verrucous carcinoma: Report of a case treated with Boyd amputation followed by reconstruction with a free forearm flap. J Dermatol 28(4): 226-230.

18. McK EE JD (2006) Carcinoma cuniculatum: A case metastasizing to skin and lymph nodes. Clinical and Experimental Dermatology 6(6): 613618.

19. Koch H, Kowatsch E, Hodl S, Smola MG, Radl R, et al. (2004) Verrucous carcinoma of the skin: long-term follow-up results following surgical therapy. Dermatol Surg 30(8): 1124-1130. 
ISSN: 2574-1241

DOI: $10.26717 /$ BJSTR.2020.26.004308

Gabriele De Sena. Biomed J Sci \& Tech Res

(C) (P) This work is licensed under Creative BY Commons Attribution 4.0 License

Submission Link: https://biomedres.us/submit-manuscript.php

\begin{tabular}{ll} 
BIOMEDICAL & \multicolumn{1}{c}{ Assets of Publishing with us } \\
RESEARCHES & - Global archiving of articles \\
- Immediate, unrestricted online access \\
- Rigorous Peer Review Process \\
https://biomedres.us/
\end{tabular}

